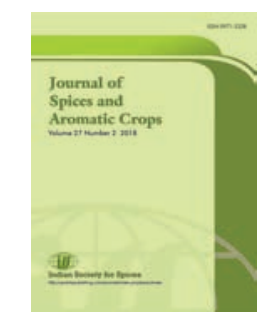

\title{
Understanding plant-beneficial microbe interactions for sustainable agriculture
}

\author{
S Ankati \& A R Podile* \\ Department of Plant Sciences, School of Life Sciences, \\ University of Hyderabad, Hyderabad-500 046, Telangana. \\ *E-mail: podilerao@gmail.com
}

Received 11 June 2018; Revised 22 September 2018; Accepted 25 October 2018

\begin{abstract}
A better understanding of the specific molecular interactions between plants and microbes is crucial to develop newer strategies for sustainable agriculture. The productivity of wide range of agricultural crops under decreasing land resources and shrinking biological potential of the soil need to be improved. Search for useful microorganisms associated with the plants has been highly productive for sustainable agriculture. We take a close look at the current level of molecular interactions that mostly involve specific molecular patterns of microbes and their cognate receptors in plants and development of efficient biofertilizers for improving crop yields. This article covers the broader aspects of plant-microbe interactions with more focus on plant growth promoting rhizobacteria (PGPR). Further upcoming strategies to understand the plant-PGPR interactions are discussed.
\end{abstract}

Keywords: biofertilizers, growth promotion, induced resistance, plant-microbe interaction, sustainable agriculture

\section{Introduction}

Plants interact with a variety of microorganisms that influence the annual crop production, and at times threaten global food security. We also have several beneficial effects of such interactions that are widely known like symbiotic nitrogen fixers and arbuscular mycorrhiza. The question here is how do plants differentiate beneficial and harmful microbes. To reduce the severity of crop losses due to the damaging effects of pathogenic microbes, antifungal and antibacterial substances are routinely used in agriculture. The prohibitive costs and the rapidity with which the microbial pathogens develop resistance increased consumer awareness on the detrimental effects of synthetic chemicals and their continued use (Neeraja et al. 2010).

The plants are able to sense evolutionarily conserved molecular pattern from microbes called microbe-associated molecular patterns (MAMPs, referred as PAMP when it originates from a pathogenic microbe) and activate responses inside the cell. These molecules are recognized by either receptor-like proteins or receptor kinases called pattern recognition receptors (PRRs) mostly localized to the plasma-membrane. 
The never-ending molecular arms race of plants against microbial pathogens, involving a multitude of PAMPs, PRRs, effectors, R proteins, via the immunity pathways are referred to as pathogen-triggered immunity (PTI) and effector triggered immunity (ETI). These pathways may hold a key to develop alternative strategies to induce disease resistance in plants. A promising and versatile PAMP, for which detailed structure/ function relationships and the molecular mode of action are currently being revealed, are chitin and chitosan oligo- and polymers (Moerschbacher 2005; Yin et al. 2010).

Chitin is the second most abundant natural polysaccharide consisting of $\beta(1,4)$-linked $N$ acetyl-D-glucosamine (GlcNAc) units in a linear form. Chitin is a major constituent of fungal cell walls as well as of insect exoskeletons and as such, chitin is a prominent PAMP indicating the presence of potentially detrimental organisms to plants. Chitin is insoluble in water and mainly exists in two crystalline ( $\alpha$ - and $\beta$-) forms (Purushotham \& Podile 2012). Chitinases (EC 3.2.1.14) hydrolyze chitin to NAG, chitobiose, or smaller chitooligosaccharides (CHOS). Chitinases are found in a wide range of organisms, including bacteria, fungi, plants, animals and are closely associated with the physiological roles of their substrates. The CHOS are gaining interest in the food, agriculture, and medicine-related industries in light of the diverse applications of these molecules. Most biological activities require CHOS with degree of polymerization $(\mathrm{DP})>4$, but the synthesis of oligomers with $>6$ DP has been a daunting task. The use of CHOS as a broad-spectrum vaccine against plant diseases highlights the need to produce specific CHOS for crop protection and production (Yin et al. 2010).

\section{Different types of plant-microbe interactions}

The interactions between plant and microbes can be either beneficial, neutral or harmful. The outcome is dependent on the delicate balance among soil and plant type. Beneficial microbes include nitrogen fixers (NF), phosphate solubilizing bacteria (PSB), vesicular-arbuscular mycorrhiza (VAM), and plant growth promoting rhizobacteria (PGPR). Mostly, these microbes are in a mutual relationship with plants for carbon source and simultaneously improve plant growth by various mechanisms. Few microbes in soil have no relation to the plant processes. Neither they get to benefit from the plant nor they provide benefit to the plant; such organisms could be classified under the neutral category of microbes. The harmful microbes referred as phytopathogens invade plants for their own benefit to get nutrients or to propagate, resulting in decrease in crop yield. Phytopathogens cause severe damage to plant developmental processes that sometimes lead to the death of plants. The estimated global crop loss was about $12.5 \%$ due to pathogenic microbes attack on plants (Oerke, 2006). Examples of different pathogenic microbes are Ralstonia solanacearum (bacteria) causing wilt in tomato, Aspergillus niger (fungi) causing crown rot in groundnut, soybean mosaic virus (virus) causing necrosis in soyabean etc.

\section{Nitrogen fixers}

Nitrogen-fixing bacteria are either in symbiotic or non-symbiotic association with the host plants. Rhizobia are well-known symbiotic NF of legumes and they fix approximately $50-300 \mathrm{~kg}$ N/ha (Mahdi et al. 2010). Rhizobia successfully form root nodules involving a classical example of exchange of chemical signals between plants and bacteria. Flavonoids like genistein, naringenin, and hesperetin from plant root exudates (REs) are reported as the signalling molecules to activate the nod genes in rhizobia, responsible for production of nod factors. Further, the nod factors take the form of lipo chito oligosaccharides (LCOs) and act as the prime molecules for plant-rhizobia specificity. $\mathrm{A} \mathrm{Ca}^{+2}$ dependent receptor kinase system of plasma membrane gets activated in the development of the nodule to maintain a symbiotic relationship (Coskun et al. 2017). Free-living Azotobacter and Azospirillum also fix nitrogen by an associative symbiotic relationship in the soil. They can fix up to 20-40 kg N ha-1 (Mahdi et al. 2010) and a specific host plant is not required for their association. Maize, sorghum, sugarcane, wheat, and pearl millet are mostly recommended by this type of NF (Rajaee et al. 2007; Gholami et al. 2009). The NF increase soil fertility, seed germination, plant growth, and produce antibiotics against pathogens. Another group of NF is blue-green algae/cyanobacteria which can fix up to $20-30 \mathrm{~kg}$ $\mathrm{N}$ ha ${ }^{-1}$ in rice fields. They are typically found in the rice fields, hence named as paddy organisms 
(Nayak et al. 2004). Azolla, a free-floating nitrogen-fixing fern is in symbiotic association with Anabaena, alleviates $\mathrm{P}, \mathrm{S}, \mathrm{K}, \mathrm{Zn}, \mathrm{Mb}$, and Fe (nutrients) deficiency to the host plant (Yatazawa et al. 1980). This Azolla-Anabaena complex is also used as a nitrogen fertilizer along with cyanobacteria to increase rice yield (Watanabe et al. 1977).

\section{Phosphate solubilizing bacteria}

Mostly phosphate in soils is available in bound form (di/tricalcium phosphate, hydroxyapatite, and rock phosphate) which cannot be absorbed by the plants. PSB can solubilize the bound phosphate and make it available to plants without using phosphate fertilizers. As a first step, PSB secrete organic acids by utilizing sugars from the plant REs and decrease the soil $\mathrm{pH}$ (Goswami et al. 2016). Later, the acid phosphatases, released by PSB, mineralize the bound phosphate for plants' uptake (Mahdi et al. 2010; Sharma et al. 2011). Aerobacter, Achromobacter, Agrobacterium, Bacillus, Burkholderia, Erwinia, Flavobacterium, Micrococcus, Pseudomonas, and Rhizobium are the few PSB. For example, Pseudomonas fluorescens and Bacillus megaterium with phosphate-solubilizing ability increased the plant growth and $\mathrm{P}, \mathrm{N}$ levels in Cicer arietinum and Phaseolus vulgaris (Sharma 2007; Collavino et al. 2010). PSB like Pantoea sp., Enterobacter sp., Burkholderia sp., and Sphingomonas sp. can also phytostabilize heavy metals (like lead and aluminum) along with phosphate solubilization in rice seedlings (Park et al. 2011; Panhwar et al. 2014). This indicates the advantage of using PSB in different situations like plant growth and phytostabilization.

\section{Vesicular-arbuscular mycorrhiza}

The Glomeromycotaphylum fungi penetrate into the vascular plant roots involving chemotaxis mediated by molecules like strigolactones and cutin of plant REs (Venturi \& Keel 2016). Such chemoattractants in the REs induce AMF to produce Myc-LCOs factors which develop vesicles and arbuscules in plant roots through a process similar to the plant-rhizobial symbiosis. The AMF capture nutrients $(\mathrm{P}, \mathrm{N}$, and $\mathrm{S}$ ) from the soil and provide to plants for their growth. This symbiotic relationship between fungi and plant root system was earlier referred as mycorrhizae. The arbuscular mycorrhizal fungi (AMF) form a sheath like protective cover around roots to protect plants from different environmental conditions like drought, salinity, other pathogenic fungal attacks. They increase the root elongation rate and improve the capturing ability of less available or inaccessible mineral nutrients $(\mathrm{Zn}, \mathrm{Co}, \mathrm{Ca}$, and $\mathrm{Mo})$ from the soil. Artemisia annua inoculated with AMF significantly increased plant growth, essential oil, and artemisinin content (Kumar et al. 2017).

A consortium of beneficial microbes was applied to test its effect on crop yield (Zaidi et al. 2017). The consortium may exhibit positive or negative effects on plants, depending on the nature of interaction between the members of the consortium. Mostly combined use of beneficial microbes resulted in increased plant growth, yield and enhanced biocontrol potential towards pathogens than their individual application (Jain et al. 2015a; Jain et al. 2015b; Sarma et al. 2015). Alagawadi \& Gaur (1994) first used the dual inoculum of Azospirillum brasilense (NF) and Pseudomonas striata or Bacillus polymyxa (PSB) on sorghum. This application increased grain yield by improving $\mathrm{N}$ and $\mathrm{P}$ absorption by the plants. In Rhizobium and PSB dual application, yield increased by $20 \%$ in comparison to their individual use in wheat (Afzal \& Bano 2008). Dual inoculation of PSB and Glomus fasciculatum also increased alfalfa plants growth (Piccini \& Azcon 1987). Rhizobium leguminosarum and AMF dual inoculation on faba bean, provided tolerance to alkaline conditions along with improved plant growth (Abd-Alla et al. 2004). This consortium of beneficial microbes is presently used in the restoration of the degraded landscape. For example, the mass multiplication of beneficial AMF, NF, and rhizobacteria in 30 legume species restored the soil fertility (Ghosh \& Dutta 2016). Out of all the tested legumes, Arachis hypogaea, showed the highest colonization by this tri-partite symbiotic relationship along with increased yield in elevated drought stress. These NF or PSB or AMF associations provide benefit to plants by increasing the nutrient availability and alleviate some environmental stress conditions.

\section{Plant growth promoting rhizobacteria (PGPR)}

Bacteria that provide benefit to plant can be 
symbiotic or free-living in the soil. They are abundant near the roots. The fraction of soil influenced by roots is called as rhizosphere (Parray et al. 2016). The term rhizosphere was first coined by a German plant physiologist and agronomist Lorenz Hiltner in 1904. In Greek the word 'rhizo' means root. The rhizosphere is divided into three zones: ectorhizosphere- soil near the root, rhizoplane- surface of the root and endorhizosphere- inside the root tissue, including cortical layers and endodermis (Badri \& Vivanco 2009; Oburger \& Schmidt 2016). The rhizosphere is colonized by a diverse group of microorganisms than the surrounding bulk soil. Approximately $10^{10}-10^{12}$ microflora will be present in a gram of rhizosphere soil, which is 1000-2000 times higher than the bulk soil microbial population. Some of the rhizobacteria in the soil promote plant growth, yield, and control diseases. Such free-living beneficial bacteria are termed as plant growth promoting rhizobacteria (PGPR) (Podile \& Kishore 2006). About 2-5\% of the total rhizosphere bacteria constitutes PGPR (Antoun 2006). Strains of the genera characterized as PGPR are Acetobacter, Acinetobacter, Aeromonas, Alcaligenes, Azoarcus, Azospirillum, Azotobacter, Arthobacter, Bacillus, Beijerinckia, Burkholderia, Clostridium, Derxia, Enterobacter, Exiguobacterium, Gluconacetobacter, Herbaspirillum, Klebsiella, Methylobacterium, Ochrobactrum, Pantoea, Paenibacillus, Pseudomonas, Rhodococcus, Serratia, Stenotrophomonas, and Zoogloea (Podile \& Kishore 2006; Chauhan et al. 2015; Jha \& Saraf 2015).

\section{Classification of plant growth promoting rhizobacteria}

PGPR are classified on the basis of functional and physiological aspects. Based on function, Somers et al. (2004) classified PGPR as biofertilizers, phytostimulators, rhizoremediators, and biopesticides. This was less accepted as the functions of PGPR are overlapping with each other. Whereas, Gray \& Smith (2005) classified PGPR into two simple groups based on their colonization ability. The intracellular PGPR (iPGPR): for bacteria colonizing inside the root (also known as endophytes) and extracellular PGPR (ePGPR): for bacteria colonizing in the rhizosphere, rhizoplane or intercellular spaces of the root. Rhizobial interaction with legumes is a simple example of iPGPR. They form nodules in the root and fix the atmospheric $\mathrm{N}$ and promote plant growth. The gram-negative, rodshaped bacterial population is dominant in iPGPR than gram-positive, cocci, rods or pleomorphic bacteria. The ePGPR are not able to form nodules, but they colonize roots and influence plant nutrient uptake, growth, and yield by an array of direct and indirect mechanisms (Fig. 1). Some PGPR directly regulate the plant processes by impersonating synthesis of plant hormones, increasing soil minerals availability, as a way to enhance growth directly (Persello-Cartieaux et al. 2003; Taurian et al. 2010). Whereas, other groups of PGPR contribute indirectly by providing biocontrol against pathogens. They compete with pathogenic microorganisms for nutrients and niche (Dutta \& Podile 2010), produce lytic enzymes and antimicrobials (Kavino et al. 2010; George et al. 2015) and induce systemic resistance (Tjamos et al. 2005) to kill the pathogens.

\section{Direct plant growth promoting mechanisms}

\section{Facilitating nutrient acquisition}

PGPR facilitate the uptake of mineral nutrients like nitrogen, phosphate, iron, and zinc from the soil by converting the nutrients to soluble form. Nitrogen is a vital mineral for many living organisms including plants. It is required for the synthesis of building blocks like nucleotides, DNA, RNA, amino acids, and proteins etc. In the atmosphere, nitrogen is available in diatomic form $(\mathrm{Na} \equiv \mathrm{N})$ with a strong triple bond. This form of nitrogen is inert and won't be able to react with any other chemicals as well as non-absorbable by plants or animals. Nitrogen-fixing PGPR convert atmospheric nitrogen into ammonia and contribute to the $\mathrm{N}$ requirement of the plants. All nitrogenfixing PGPR possess metalloenzymes known as nitrogenase, coded by nif genes. They include structural genes, iron protein activating genes, iron-molybdenum cofactor biosynthesis genes and regulatory genes necessary for the nitrogen fixation. Nitrogen-fixing Pseudomonas strain K1 increased grain yield and shoot biomass of two basmati rice varieties in comparison to non-nitrogen fixing Zoogloea, Azospirillum brasilense, and Azospirillum lipoferum (Mirza et al. 2006). A similar result was observed by Kuan et al. (2016) in maize with nitrogen-fixing Klebsiella sp., Bacillus pumilus, and Acinetobacter sp. inoculation. 
After nitrogen, phosphorus is the second most essential macronutrient required for the growth of plants. Mostly phosphate exists in insoluble form, even in phosphate-rich soils. PGPR or PSB secrete organic acids (gluconic, glycolic, malonic, oxalic, and succinic acid) and phosphatases to disturb soil phosphate dynamics. They convert insoluble phosphates into soluble mono or di basic $\left(\mathrm{H}_{2} \mathrm{PO}_{4}^{-}\right.$and $\left.\mathrm{HPO}_{4}^{2-}\right)$ ions, referred as mineral phosphate solubilization (Mallick 2016). This leads to an increase in phosphate availability in rhizosphere and plants phosphate utilization. Bacillus, Enterobacter, Erwinia and Pseudomonas spp. are the most potent PSBs (Gyaneshwar et al. 2002). As an example, a gluconic acid producing endophytic Pseudomonas sp. improved growth and yield of Pisum sativum L. in phosphatelimiting conditions (Oteino et al. 2015).

Like phosphate, zinc also exists as insoluble complexes in soil and cannot be utilized by the plants. PGPR fulfil the plant's zinc requirement by solubilizing zinc complexes and releasing zinc into the rhizosphere. Zinc solubilization is achieved by production of organic acids, inorganic acids (sulphuric acid, nitric acid, and carbonic acid), chelating ligands, proton extrusion, and/or with the oxidoreductive systems present on the cell membranes of PGPR (Wakatsuki 1995; Saravanan et al. 2004; Goteti et al. 2013).

\section{Phytohormones production}

Phytohormones are plant growth regulators that influence plant development; produced by plants, algae, and few prokaryotic microorganisms. There are five important phytohormones, i.e. auxins, gibberellic acids, cytokinins, abscisic acid, and ethylene. PGPR secreted phytohormones influence the root zone and the plant developmental process. For instance, indole-3acetic acid (IAA) is an auxin that controls many important plant physiological processes, that include cell elongation, cell division, tissue differentiation, lateral root formation, and response to light and gravity (Parray et al. 2016). PGPR with IAA producing capability will have a capability to regulate these developmental processes by adding IAA to the plant's auxin pool (Vessey 2003). Plant's potential to absorb nutrients and water depends on the root surface area. The increase in root surface by IAA improves absorption capacity from large volume of soil and their utilization for plant growth (Volkmar \& Bremer 1998).

Gibberellic acids (GA) are tetracyclic diterpene compounds that promote seed germination, sex expression, stem elongation, flowering, and senescence in plants. They are produced by higher plants, bacteria, and fungi. All the GAs available in the rhizosphere are not biologically active. PGPR with potential to deconjugate gibberellin-glucosyl bonds can generate active dihydroxylated GAs (like GA1, GA3, and GA4) in the root zone. This active form of GAs promotes plant growth. For example, Bacillus cereus, B. macrolides, and B. pumilus significantly increased red pepper growth by producing biologically active GAs (Joo et al. 2004). A new PGPR, Leifsoniasoli SE134 also influenced the growth and yield of cucumber, rice, tomato, and radish by producing active GAs (Kang et al. 2014). The third group of phytohormones, cytokinins are involved in cell division of root and shoot formation. Arabidopsis thaliana mutants lacking cytokinin signalling genes (Cre1, Ahk2 and Ahk3, and Rpn12) showed impaired plant growth in presence of plant growth promoting Bacillus megaterium. This shows the complementary role of cytokinin and PGPR in plant growth promotion (Ortíz-castro et al. 2008). Other two phytohormones abscisic acid (ABA) and ethylene are stress-tolerant hormones. ABA influences seed dormancy and bud growth, whereas ethylene affects the cell shape and growth. A. thaliana elevated salt stress in presence of Azospirillum brasilense and showed a two-fold increase of plant ABA content (Cohen et al. 2008). This explains the importance of ABA in stress tolerance along with growth promotion. Plant internal ethylene levels are triggered by many biotic and abiotic factors. The increased ethylene levels inhibit plant growth by hindering DNA synthesis and cell division processes. PGPR are able to synthesize 1-aminocyclopropane-1carboxylate (ACC) deaminase can counteract the negative effects of ethylene via decreasing its levels. The ACC deaminase cleaves ACC, the precursor of ethylene into ammonia and $\alpha$-ketobutyrate. Pseudomonas putida inoculated Papaver somniferum plants resisted against the negative effects of downy mildew (caused by Peronospora sp.) by 
decreasing ACC levels, increasing IAA and significantly improved the plant growth. Rkh1Rkh4 PGPR, isolated from weed rhizosphere showed significant growth promotion of soybean by secreting IAA, GA, and ABA to elevated salt stress (Naz et al. 2009), indicating the interlink of phytohormones secreted by PGPR in regulating growth and stress alleviation in plants.

\section{Siderophores production}

Iron is an important micronutrient and serves as a cofactor for many redox maintaining enzymes of cell. Iron is available in insoluble ferric hydroxide form in soils. This limits the iron availability even in iron-rich regions for proper plant growth. Siderophores are low molecular weight, small, iron chelating compounds released by the bacteria (including PGPR), fungi and plants. The siderophores have a high affinity to $\mathrm{Fe}^{3+}$ and form $\mathrm{Fe}^{3+}$-siderophore complexes that are absorbed by the plants. Plants have adapted mechanisms to absorb $\mathrm{Fe}^{3+}$ bound to the bacterial siderophores (Masalha et al. 2000) by ligand exchange process. PGPR with siderophore producing ability can chelate iron in the soil and make it available to plant, and limit its availability to pathogens that cannot produce affinity siderophores. This generates a competition between PGPR and pathogen for iron utilization. Further, they suppress pathogens by inducing defense mechanisms of the plant. Pyoverdine, a yellow-green pigment produced by many fluorescent Pseudomonads functions as siderophore, and suppresses the pathogens (Becker \& Cook 1988). Few siderophores can even chelate heavy metals and radionuclides (such as $\mathrm{Al}, \mathrm{Cu}, \mathrm{Cd}, \mathrm{In}, \mathrm{Ga}, \mathrm{Pb}, \mathrm{U}$, and $\mathrm{Np}$ ) and alleviate the stress imposed on plants (Neubauer et al. 2000).

\section{Indirect mechanisms of plant growth promotion}

PGPR effectively compete with pathogens for nutrients or niche by releasing lytic enzymes/ antimicrobial compounds and by inducing systemic resistance (Podile \& Kishore 2006) in plants (Fig. 1).

\section{Antibiosis against pathogenic microbes}

A biological association of two or more microorganisms, in which one is detrimental to another by its antagonistic behaviour, is called as antibiosis. PGPR secrete a wide variety of antibiotics to suppress phytopathogens. These antibiotics can be antibacterial or antifungal and inhibit pathogens even at very low concentrations. Some reported antibiotics produced by Pseudomonads are aerugine, amphisin, azomycin, butyrolactones, cepaciamide A, ecomycins, hydrogen cyanide, 2,4diacetylphloroglucinol, phenazine, oomycin A, pyoluteorin, tensin, tropolone, pyrrolnitrin, viscosinamide, cyclic lipopeptides, rhamnolipids, kanosamine, zwittermycin-A, pseudomonic acid, antitumor antibiotics, cepafungins, and karalicin. They are reported to have antimicrobial, antioxidant, antitumor, antiviral, antihelminthic, cytotoxic, phytotoxic activities and plant growth promotion (Goswami et al. 2016; Parray et al. 2016). Antibiotics produced by Streptomyces, Bacillus, and Stenotrophomonas include oligomycin A, kanosamine, zwittermicin A and xanthobaccin (Parray et al. 2016). The volatile hydrogen cyanide $(\mathrm{HCN})$, among them, inhibits cytochrome $\mathrm{C}$ oxidase, an important electron transport chain enzyme and reduces the energy supply to cell. This eventually leads to death of pathogen. As the $\mathrm{HCN}$ is not a specific inhibitor of pathogens, it may inhibit PGPR or plant energy mechanisms as well. The phytotoxic effects of $\mathrm{HCN}$ in reducing plant growth is also reported in crops (Devi et al. 2007; Kumar et al. 2015). Rijavec \& Lapanje (2016) proposed the phosphate regulating ability of $\mathrm{HCN}$, over the biocontrol activity against pathogens, which needs further evaluation.

\section{Induced systemic resistance}

PGPR or antimicrobial compounds released by them, trigger a mild innate immune response after colonizing plants, which is referred as priming. First, microbe-associated molecular patterns of PGPR are recognized by pattern recognition receptors of plant cells. Later, the plant develops an induced systemic resistance (ISR) by producing phytoalexins, expressing PR proteins, activating mitogen-activated protein kinase, and altering cellular calcium $\left(\mathrm{Ca}^{2+}\right)$ levels. This prepares the plant to fight against subsequent pathogens attack. ISR in plants is attained by activating the signalling pathways regulated by jasmonic acid or salicylic acid or ethylene. In 


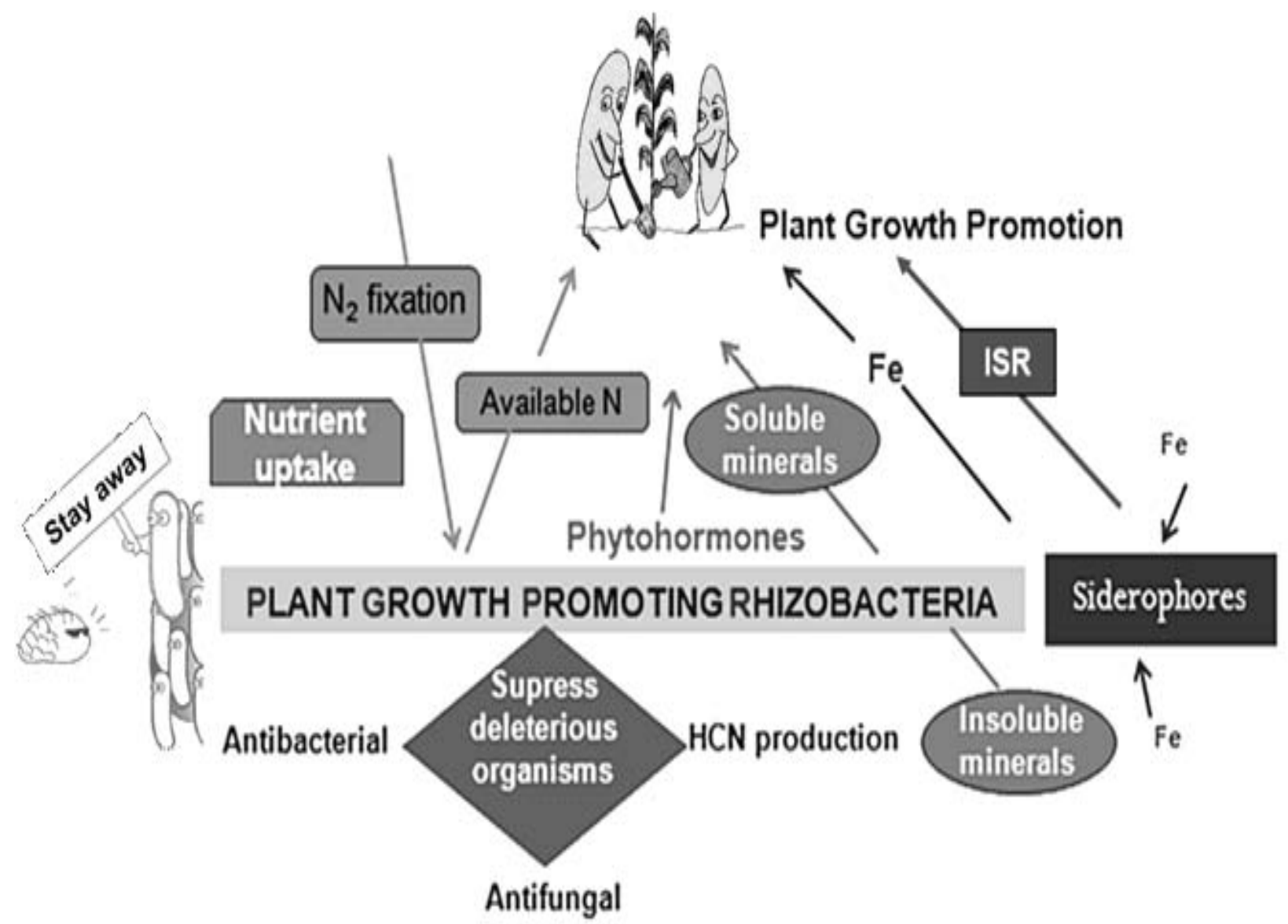

Fig. 1. Overview of plant growth promotion by PGPR: Direct and indirect mechanisms in improving the plant growth. They increase nitrogen (N), phosphate, zinc, and iron (Fe) availability and release phytohormones for improving plant growth. Antimicrobial metabolites, lytic enzymes, and siderophores secreted by PGPR prevent pathogens attack by ISR.

Pseudomonas spp. ' $\mathrm{O}$ ' antigenic side chain of lipopolysaccharides, 2, 4-diacetylphloroglucinol, volatiles (like, acetoin and 2,3-butanediol), siderophores (like pseudobactin and pseudomanine), flagella, cyclic lipopeptides, and homoserine lactones are few determinants of ISR in plants (Ryu et al. 2004; Gupta et al. 2015; Goswami et al. 2016). Diseases and damage caused by fungi, bacteria, viruses, nematodes and insects can be reduced by the PGPR application through activation of ISR (Ramamoorthy et al. 2001; Sivakumar et al. 2015; Sreeja et al. 2016; Bhai et al. 2017; Aswathi \& Ushamalini 2017). Inoculation of Bacillus velezensis, B. mojavensis, B. safensis, B. subtilis, and B. altitudinis individually or in mixtures, reduced the Heterodera glycines (nematode) population and increased yield of soybean by activating the ISR (Xiang et al. 2017). B. pumilus SE34, Pseudomonas fluorescens 89B61, and P. putida inoculation in tomato plants reduced the late blight (fungal) disease and Spodoptera litura (insect) infestation by exerting ISR (Yan et al. 2002; Bano \& Muqarab 2017). From this, ISR can be considered as a crucial defense mechanism in plants against most of the pathogens like nematodes, insects, and fungi.

\section{Cell wall degrading enzymes}

Several PGPR show hyperparasitic activity on fungal pathogens by producing fungal cell wall degrading enzymes. As the fungal cell walls have a considerable amount of chitin and $\beta$-glucans as structural components, chitinases, and $\beta$ glucanases are considered as major mycolytic enzymes active against the number of phytopathogenic fungi (García-Cristobal et al. 2015; Kim et al. 2015). Degrading fungal cell walls 
by these enzymes inhibits the fungal growth and propagation. Chitinase producing PGPR include Bacillus spp., Serratia marcescens, Enterobacter agglomerans, Pseudomonas aeruginosa, and $P$. fluorescens. Few glucanase producers are Paenibacillus, B. Cepacia and Streptomyces (Goswami et al. 2016). This is the major mechanism adapted by most of the PGPR to overcome fungal attacks in plants.

\section{Drawbacks of PGPR biofertilizers}

Currently, a number of PGPR, with potential to enhance crop yield, are being commercialized. Various PGPR have been formulated individually or in a consortium for plant growth and defense against pathogens. Groundnut yield was significantly increased in combined application of Rhizobium, Pseudomonas, and Bacillus (Mathivanan et al. 2014). Defense against anthracnose, angular leaf spot, and wilt causing pathogens in cucumber plants was reported by Raupach \& Kloepper (1998) by application of $B$. subtilis, B. pumilus, and Curtobacterium flaccumfaciens.

The main drawback in using PGPR as biofertilizers is their inconsistency and irreproducibility in their performance under field conditions. The variation in PGPR biofertilizers performance is due to environmental factors that affect their stability and growth. Eventually, this hinders their potential growth promotion in plants. About $90 \%$ of the applied biofertilizer is noted to be lost into the air while applying and not used by the plants (Vejan et al. 2016). The remaining population might not be optimum for colonization. Ultimately this leads to a rapid decline in the population (Arora et al. 2010). This might be one of the reasons for negative results in the field conditions vs. positive outcomes in the laboratory observations. Other factors affecting may be the poor expertise of farmers for inoculum application, handling, storage, and large field area for inoculation (Bashan et al. 2014).

Upcoming strategies to overcome disadvantages of biofertilizers

To maximize interactions of nursery seedlings and PGPR, it is essential to determine, how they exert their positive effects on plants.
Understanding the interactions at molecular and physiological levels (Vessey 2003) with the focus on genes, proteins, and metabolites (Parray et al. 2016) can fill the gaps. New concepts like rhizoengineering for pointing the exotic biomolecules responsible for the plant-microbe interactions (Gupta et al. 2015) and nanotechnology for the production of PGPR based nano-fertilizer for an efficient application (Vejan et al. 2016) can be potent alternatives. Gregorio et al. (2017) generated nanofibers immobilized with PGPR; Pantoea agglomerans and Burkholderia caribensis. The coating of soybean seeds with these fibers showed increased plant growth. The processes involved in the colonization of PGPR to the root system and chemical signalling involved in plantPGPR interactions need special attention, to increase the usage of PGPR in agriculture.

\section{Chitosan-based PGPR biofertilizer}

Chitosan is a biologically active linear polymer. It is made of D-glucosamine and $N$-acetyl-Dglucosamine units linked by $\beta-(1,4)$-glycosidic bond. Chitin, the major cellular component of fungal cell walls, insects, crustaceans acts as a precursor for generating chitosan. Chitosan is a deacetylated form of chitin. It has many applications in pharmaceuticals, biopesticides, and plant growth enhancement. Chitosan induces the synthesis of callose, lignin, defense response and phytoalexins in plants. Use of chitosan in biofertilizers to alleviate fungal diseases in crop plants is in trend. For example, crustaceous chitosan and Cunninghamella elegans chitosan alleviated Fusarium oxysporum infection in cowpea plants by inducing catalase, reactive oxygen species, and peroxidases (Berger 2016). The pinewood nematode, Bursaphelenchus xylophilus causes severe wood damage in pine plants. Application of chitosan in soil reduced the nematode population and damage caused by them (Silva et al. 2014). A combined application of diazotrophic bacteria (with N, P, K, accumulation ability) and crustaceous chitosan improved cowpea nodules formation, shoot biomass and yield by increasing nutrients availability (Berger et al. 2013). Along with agricultural applications, chitosan also had many pharmacological uses like drugs, siRNA, DNA, and proteins delivery in humans. Ippolito et al. (2017) studied crustacean chitosan role in 
inhibition of potato pathogens Phytophthora infestans and Fusarium solani. These findings indicate the role of chitosan as an elicitor and growth promoter in biofertilizers. Chitosan amendment can add an additional benefit in preparing an efficient biofertilizer.

\section{Acknowledgments}

The authors thank the committee that selected ARP for the Dr. Y. R. Sarma memorial lecture, DST-FIST Level II support from Department of Science and Technology, Government of India, and the UGC-SAP programme of the Department of Plant Sciences. ARP also thanks DBT for the Tata Innovation Fellowship while SA thanks CSIR for the senior research fellowship.

\section{References}

Abd-Alla M H, El-Enany A W, Nafady N A, Khalaf D M \& Morsy F M 2004 Synergistic interaction of Rhizobium leguminosarum bv. viciae and arbuscular mycorrhizal fungi as a plant growth promoting biofertilizers for faba bean (Vicia faba L.) in alkaline soil. Microbiol. Res. 169: 49-58.

Afzal A \& Bano A 2008 Rhizobium and phosphate solubilizing bacteria improve the yield and phosphorus uptake in wheat (Triticum aestivum). Int. J. Environ. Agri. Res. 10: 85-88.

Alagawadi A R \& Gaur A C 1994 Inoculation of Azospirillum brasilense and phosphatesolubilizing bacteria on yield of sorghum (Sorghum bicolor L. Moench) in dry land. AGRIS 69: 347-350.

Antoun H \& Prevost D 2006 Ecology of plant growth promoting rhizobacteria. In: Siddiqui Z A (Ed.), PGPR: Biocontrol and Biofertilization. Springer, Dordrecht.

Arora N K, Khare E \& Maheshwari D K 2010 Plant growth and health promoting bacteria: constraints in bioformulation, commercialization, and future strategies. In: Maheshwari D K (Ed.), Plant growth and health promoting bacteria, Microbiology, pp.97-116.

Aswathi S \& Ushamalini C 2017 Bacillus subtilis, a potential biocontrol agent for the management of coriander wilt. J. Spices Arom. Crops 26: 136-140.
Badri D V \& Vivanco J M 2009 Regulation and function of root exudates. Plant Cell Environ. 32: 666-681.

Bano A \& Muqarab R 2017 Plant defence induced by PGPR against Spodoptera litura in tomato (Solanum lycopersicum L.). Plant Biol. 19: 406412.

Bashan Y, Bashan L E, Prabhu S R \& Hernandez J P 2014 Advances in plant growth-promoting bacterial inoculant technology/ : formulations and practical perspectives (1998-2013). Plant Soil 378: 1-33.

Berger L R R, Stamford N P, Santos C E R S, Freitas A D S, Franco L O \& Stamford T C M 2013 Plant and soil characteristics affected by biofertilizers from rocks and organic matter inoculated with diazotrophic bacteria and fungi that produce chitosan. J. Soil Sci. Plant Nutr. 13: 592-603.

Berger L R R, Stamford N P, Willadino L G, Laranjeira D, Lima M A B, Malheiros S M M, Oliveira W J \& Stamford T C M 2016 Cowpea resistance induced against Fusarium oxysporum f.sp. tracheiphilum by crustaceous chitosan and by biomass and chitosan obtained from Cunninghamella elegans. Biol. Control 92: 4554.

Bhai R S, Eapen S J, Kumar A, Aravind R, Pervez R, Varghese E M, Krishna P B \& Sreeja K 2017 Mitigating Phytophthora foot rot and slow decline diseases of black pepper through the deployment of bacterial antagonists. J. Spices Arom. Crops 26: 69-82.

Chauhan H \& Bagyaraj D J, Selvakumar G \& Sundaram S P 2015 Novel plant growth promoting rhizobacteria- Prospects and potential. Appl. Soil Ecol. 95: 38-53.

Cohen A C, Bottini R \& Piccoli P N 2008 Azospirillum brasilense Sp 245 produces ABA in chemicallydefined culture medium and increases ABA content in Arabidopsis plants. J. Plant Growth Regul. 54: 97-103.

Collavino M M, Sansberro P A, Mroginski L A \& Aguilar O M 2010 Comparison of in vitro solubilization activity of diverse phosphatesolubilizing bacteria native to acid soil and their ability to promote Phaseolus vulgaris growth. Biol. Fertil. Soils 46: 727-738.

Coskun D, Britto D T, Shi W \& Kronzucker H J 2017 How Plant Root Exudates Shape the Nitrogen Cycle. Trends Plant Sci. 22: 661-673. 
Devi K K, Seth N, Kothamasi S \& Kothamasi D 2007 Hydrogen cyanide producing rhizobacteria kill subterranean termite Odontotermes obesus (Rambur) by cyanide poisoning under in vitro conditions. Curr. Microbiol. 54: 74-78.

Dutta S \& Podile AR 2010 Plant growth promoting rhizobacteria (PGPR): the bugs to debug the root zone. Crit. Rev. Microbiol. 36: 232-244.

García-Cristobal J, García-Villaraco A, Ramos B, Gutierrez-Mañero J \& Lucas J A 2015 Priming of pathogenesis related-proteins and enzymes related to oxidative stress by plant growth promoting rhizobacteria on rice plants upon abiotic and biotic stress challenge. J. Plant Physiol. 188: 72-79.

George E, Kumar S N, Jacob J, Bommasani B, Lankalapalli R S, Morang P \& Kumar B S D 2015 Characterization of the bioactive metabolites from a plant growth-promoting rhizobacteria and their exploitation as antimicrobial and plant growth-promoting agents. Appl. Biochem. Biotechnol. 176: 529546.

Gholami A, Shahsavani S \& Nezarat S 2009 The effect of plant growth promoting rhizobacteria (PGPR) on germination, seedling growth and yield of maize. International Journal of Agricultural and Biosystems Engineering Int. J. Agric. Biosys. Eng. 3: 9-14.

Ghosh A \& Dutta S 2016 Investigation on arbuscular mycorrhizal colonization on the roots of some members of Fabaceae and selection of suitable hosts for mass multiplication of VAM. Int. J. Adv. Res. Biol. Sci. 3: 193-197.

Goswami D, Thakker J N \& Dhandhukia P C 2016 Portraying mechanics of plant growth promoting rhizobacteria (PGPR): A review. Cogent Food Agric. 2: 1-19.

Goteti P K, Emmanuel L D A, Desai S \& Shaik M H A 2013 Prospective zinc solubilising bacteria for enhanced nutrient uptake and growth promotion in maize (Zea mays L.). Int. J. Microbiol. 2013: 1-7.

Gray E J \& Smith D L 2005 Intracellular and extracellular PGPR: Commonalities and distinctions in the plant-bacterium signaling processes. Soil. Biol. Biochem. 37: 395-412.

Gregorio P R D, Michavila G, Muller L R, Borges C S, Sa E L S, Pereira C \& Vincent P A 2017 Beneficial rhizobacteria immobilized in nanofibers for potential application as soybean seed bioinoculants. PLoS One 12: 122.

Gupta G, Parihar S S, Ahirwar N K, Snehi S K \& Singh V 2015 Plant Growth Promoting Rhizobacteria (PGPR): current and future prospects for development of sustainable agriculture. J. Microb. Biochem. Technol. 7: 96-102.

Gyaneshwar P, Kumar G N, Parekh L J \& Poole P S 2002 Role of soil microorganisms in improving P nutrition of plants. Plant Soil 245: 83-93.

Ippólito S D, Mendieta J R, Terrile M C, Tonon C V, Mansilla A Y, Colman S, Albertengo L, Rodríguez M S \& Casalongué C A 2017 In: E A Shalaby (Ed.), Chitosan as source for pesticide formulations. Biological activities and application of marine polysaccharides. pp. 315.

Jain A, Singh A, Singh S \& Singh H B 2015a Phenols enhancement effect of microbial consortium in pea plants restrains Sclerotinia sclerotiorum. Biol. Control 89: 23-32.

Jain A, Singh A, Singh S \& Singh H B 2015b Biological management of Sclerotinia sclerotiorum in pea using plant growth promoting microbial consortium. J. Basic Microbiol. 55: 961-972.

Jha C K \& Saraf M 2015 Plant growth promoting rhizobacteria (PGPR): a review. J. Agr. Res. Dev. 5:108-119.

Joo G, Kim Y, Lee I, Song K \& Rhee I 2004 Growth promotion of red pepper plug seedlings and the production of gibberellins by Bacillus cereus, Bacillus macroides and Bacillus pumilus. Biotechnol. Lett. 26: 487-491.

Kang S, Khan A L, You Y, Kim J, Kamran M \& Lee I 2014 Gibberellin production by newly isolated strain Leifsonia soli SE134 and its potential to promote plant growth. J. Microbiol. Biotechnol. 24: 106-112.

Kavino M, Harish S, Kumar N, Saravanakumar D \& Samiyappan R 2010 Effect of chitinolytic PGPR on growth, yield and physiological attributes of banana (Musa spp.) under field conditions. Appl. Soil Ecol. 45: 71-77.

Kim J, Lee J, Lee C, Woo S Y, Kang H, Seo S \& Kim S 2015 Activation of Pathogenesis-related Genes by the Rhizobacterium, Bacillus sp. JS, which induces systemic resistance in tobacco plants. Plant Pathol. J. 31: 195-201. 
Kuan K B, Othman R, Rahim K A \& Shamsuddin Z H 2016 Plant growth-promoting rhizobacteria inoculation to enhance vegetative growth, nitrogen fixation and nitrogen remobilisation of maize under greenhouse conditions. PLoS One 11: 1-19.

Kumar A, Bahadur I, Maurya B R, Raghuwanshi R, Meena V S, Singh D K \& Dixit J 2015 Does a plant growth promoting rhizobacteria enhance agricultural sustainability? J. Pure Appl. Microbiol. 9: 715-724.

Kumar A, Singh D R, Latha S \& Johri R M 2017 Effect of arbuscular mycorrhizal fungi on plant growth and essential oil and artemisinin content of Artemisia annua L. Int. J. Pharm. BioSci. 11: 33-44.

Mahdi SS, Hassan G I, Samoon S A, Rather H A, Dar S A \& Zehra B 2010 Bio-fertilizers in organic agriculture. J. Phytol. 2: 42-54.

Mallick M A 2016 Phosphate solubilizing microbes: an effective and alternative approach as biofertilizers. Int. J. Pharm. Pharmaceutical Sci. 8: 37-40.

Masalha J, Kosegarten H, Elmaci Ö \& Mengel K 2000 The central role of microbial activity for iron acquisition in maize and sunflower. Biol. Fertil. Soils 30: 433-439.

Mathivanan S, Chidambaram A A, Sundramoorthy P, Baskaran L \& Kalaikandhan R 2014 Effect of combined inoculations of plant growth promoting rhizobacteria (PGPR) on the growth and yield of groundnut (Arachis hypogaea L.). Int. J. Curr. Microbiol. App. Sci. 3: 1010-1020.

Mirza M S, Mehnaz S, Normand P, Prigent-Combaret C, Moënne-Loccoz Y, Bally R \& Malik K A 2006 Molecular characterization and PCR detection of a nitrogen-fixing Pseudomonas strain promoting rice growth. Biol. Fertil. Soils 43: 163-170.

Moerschbacher B M 2005 Bio-activity matrices of chitosans in plant protection. In: $S$ S Gnanamanickam, R Balasubramanian, N Anand (Eds.), Emerging Trends in PlantMicrobe Interactions. University of Madras, Chennai, pp.186-190.

Nayak S, Prasanna R, Pabby A, Dominic T K \& Singh P K 2004 Effect of urea, blue green algae and Azolla on nitrogen fixation and chlorophyll accumulation in soil under rice. Biol. Fertil. Soils 40: 67-72.
Naz I, Bano A \& Hassan T U 2009 Isolation of phytohormones producing plant growth promoting rhizobacteria from weeds growing in Khewra salt range, Pakistan and their implication in providing salt tolerance to Glycine max L. Afr. J. Biotechnol. 8: 57625766 .

Neeraja C, Anil K, Purushotham P, Suma K, Sarma P V S R N, Moerschbacher B M \& Podile A R 2010 Biotechnological approaches to develop bacterial chitinases as a bioshield against fungal diseases of plants, Crit. Rev. Biotechnol. 30: 231-241.

Neubauer U, Nowack B, Furrer G \& Schulin R 2000 Heavy metal sorption on clay minerals affected by the siderophore desferrioxamine B. Environ. Sci. Technol. 34: 2749-275.

Oburger E \& Schmidt H 2016 New methods to unravel rhizosphere processes. Trends Plant Sci. 21: 243-255.

Oerke E C 2006 Crop losses to pests. J. Agri. Sci. 144: 31-43.

Ortíz-castro R, Valencia-cantero E \& López-bucio J 2008 Plant growth promotion by Bacillus megaterium involves cytokinin signaling. Plant Signal Behav. 3: 263-264.

Oteino N, Lally R D, Kiwanuka S, Lloyd A, Ryan D, Germaine K J \& Dowling D N 2015 Plant growth promotion induced by phosphate solubilizing endophytic Pseudomonas isolates. Front. Microbiol. 6: 1-9.

Panhwar Q A, Naher UA, Jusop S, Othman R, Latif M A \& Ismail M R 2014 Biochemical and molecular characterization of potential phosphate-solubilizing bacteria in acid sulfate soils and their beneficial effects on rice growth. PLoS One 9: 1-14.

Park J H, Bolan N, Megharaj M \& Naidu R 2011 Isolation of phosphate solubilizing bacteria and their potential for lead immobilization in soil. J Hazard. Mater. 2: 829-836.

Parray J A, Jan S, Kamili A N \& Qadri R A 2016 Current perspectives on plant growthpromoting rhizobacteria. J. Plant Growth Regul. 35: 877-902.

Persello-Cartieaux F, Nussaume L \& Robaglia C 2003 Tales from the underground: Molecular plantrhizobacteria interactions. Plant Cell Environ. 26: 189-199. 
Piccini D \& Azcon R 1987 Effect of phosphatesolubilizing bacteria and vesiculararbuscular mycorrhizal fungi on the utilization of Bayovar rock phosphate by alfalfa plants using a sand-vermiculite medium. Plant Soil 101: 45-50.

Podile A R \& Kishore K 2006 Plant growthpromoting rhizobacteria. Annu. Rev. Microbiol. 63: 195-230.

Purushotham P \& Podile A R 2012 Synthesis of longchain chitooligosaccharides by a hypertransglycosylating processive endochitinase of Serratia proteamaculans 568. J. Bacteriol. 194: 4260-4271.

Rajaee S, Alikhani H A \& Raiesi F 2007 Effect of plant growth promoting potentials of Azotobacter chroococcum native strains on growth, yield and uptake of nutrients in wheat. J. Water Soil Sci. 11: 285-297.

Ramamoorthy V, Viswanathan R, Raguchander T, Prakasam V \& Samiyappan R 2001 Induction of systemic resistance by plant growth promoting rhizobacteria in crop plants against pests and diseases. Crop Prot. 20: 111.

Raupach G S \& Kloepper J W 1998 Mixtures of plant growth-promoting rhizobacteria enhance biological control of multiple cucumber pathogens. Biol. Control 88: 1158-1164.

Rijavec T \& Lapanje A 2016 Hydrogen cyanide in the rhizosphere/ : not suppressing plant pathogens, but rather regulating availability of phosphate. Front. Microbiol. 7: 1-14.

Ryu C, Farag M A, Hu C, Reddy M S, Kloepper J W \& Pare P W 2004 Bacterial volatiles induce systemic resistance in Arabidopsis. Plant Physiol. 134: 1017-1026.

Saravanan V S, Subramoniam S R \& Raj S A 2004 Assessing in vitro solubilization potential of different zinc solubilizing bacterial (ZSB) isolates. Braz. J. Microbiol. 35: 121-125.

Sarma B K, Yadav S K, Singh S \& Singh H B 2015 Microbial consortium-mediated plant defense against phytopathogens: Readdressing for enhancing efficacy. Soil Biol. Biochem. 87: 25-33.

Sharma 2007 Effect of phosphate solubilizing bacteria on the germination of Cicer arietinum seeds and seedling growth. J. Herb. Med. Toxicol. 1: 61-63.
Sharma S, Kumar V \& Tripathi R B 2011 Isolation of phosphate solubilizing microorganism (PSMs) from soil. J. Microbiol. Biotechnol. Res.1: 90-95.

Silva M N, Carvalho V G B, Sarmento B, Stamford N P, Pintado M E \& Vasconcelos M W 2014 Effect of a chitosan enriched biofertilizer on induced resistances against the pinewood nematode, Bursaphelenchus xylophilus, in: $11^{\text {th }}$ International Conference of the European Chitin Society, at Porto, Portugal.

Sivakumar G, Dhanya M K \& Murugan M 2015 Induced defense response in small cardamom plants by Bacillus subtilis strain Bs against capsule rot pathogen, Phytophthora meadii. J. Spices Arom. Crops 24: 12-17.

Somers E, Vanderleyden J \& Srinivasan M 2004 Rhizosphere bacterial signalling: a love parade beneath our feet. Crit. Rev. Microbiol. 30: 205-240.

Sreeja K, Anandaraj M \& Bhai R S 2016 In vitro evaluation of fungal endophytes of black pepper against Phytophthora capsici and Radopholus similis. J. Spices Arom. Crops 25: 113-122.

Taurian T, Anzuay M S, Angelini J G, Tonelli M L, Ludueña L, Pena D, Ibáñez F \& Fabra A 2010 Phosphate-solubilizing peanut associated bacteria: Screening for plant growthpromoting activities. Plant Soil 329: 421-431.

Tjamos S E, Flemetakis E, Paplomatas E J \& Katinakis P 2005 Induction of resistance to Verticillium dahliae in Arabidopsis thaliana by the biocontrol agent K-165 and pathogenesis-related proteins gene expression. MPMI/ 18: 555-561.

Vejan P, Abdullah R, Khadiran T, Ismail S \& Boyce A N 2016 Role of plant growth promoting rhizobacteria in agricultural sustainabilityA review. Molecules 21: 1-17.

Venturi V \& Keel C 2016 Signaling in the Rhizosphere. Trends Plant Sci. 21:187-198.

Vessey J K 2003 Plant growth promoting rhizobacteria as biofertilizers. Plant Soil 255: 571-586.

Volkmar K M \& Bremer E 1998 Effects of seed inoculation with a strain of Pseudomonas fluorescens on root growth and activity of wheat in well-watered and drought-stressed glass-fronted rhizotrons. Can. J. Plant Sci. 78, 545-551. 
Wakatsuki T 1995 Metal oxidoreduction by microbial cells. J. Ind. Microbiol. Biotechnol. 14: 169-177.

Watanabe I, Espinas C R, Berja N S \& Alimagno B V 1977 The utilization of the Azolla - Anabaena complex as a nitrogen fertilizer for rice. Monograph. International Rice Research Institute, Manila, Philippines.

Xiang N, Lawrence K S, Kloepper J W, Donald P A \& McInroy J A 2017 Biological control of Heterodera glycines by spore-forming plant growth-promoting rhizobacteria (PGPR) on soybean. PLoS One 12: 1-19.

Yan Z, Reddy M S, Ryu C, Mcinroy J A, Wilson M \& Kloepper J W 2002 Induced systemic protection against tomato late blight elicited by plant growth-promoting rhizobacteria. Biol. Control 92: 1329-1333.

Yatazawa M, Tomomatsu N \& Hosoda N 1980 Soil Science and plant nutrition nitrogen fixation in Azolla-Anabaena symbiosis as affected by mineral nutrient status. J. Soil Sci. Plant Nutr. 26: 415-426.

Yin H, Zhao X M \& Du Y G 2010 Oligochitosan: a plant diseases vaccine- a review. Carbohydr. Polym. 82:1-8.

Zaidi A, Ahemad M, Oves M, Ahmad E \& Khan M S 2017 Role of phosphate-solubilizing bacteria in legume improvement. In: M S Khan, J Musarrat \& A Zaidi (Eds.), Microbes for Legume Improvement (pp.175-197), Springer, Cham. 